\title{
Medium optimization for production of L-Glutaminase (EC 3.5.1.2) by Streptomyces griseus under submerged fermentation
}

\author{
Suresh kumar.S \\ Department of Chemical Engg, \\ Annamalai University, \\ Annamalai nagar, India.
}

\author{
R. Muthuvelayudham \\ Department of Chemical Engg, \\ Annamalai University, \\ Annamalai nagar, India.
}

\author{
T. Viruthagiri \\ Department of Chemical Engg, \\ Annamalai University, \\ Annamalai nagar, India.
}

\begin{abstract}
L-Glutaminase is widely distributed in microorganisms including bacteria, yeast and fungi. The enzyme mainly catalyzes the hydrolysis of $\gamma$-amido bond of 1-glutamine. In this report medium optimization was conducted through one -factor -at -a -time approach for the submerged production of L-Glutaminase by Streptomyces griseus using different additional carbon, nitrogen, amino acids, mineral salts and was treated with different concentration sodium chloride. A significant influence of medium components ( $\mathrm{g} / \mathrm{l}$ ) Galactose 10.0, Yeast extract 10.0,L-Glutamine 10.0,Magnesium sulphate 0.5, $\mathrm{KH}_{2} \mathrm{PO}_{4} 0.5, \mathrm{~K}_{2} \mathrm{HPO}_{4} 0.5, \mathrm{NaCl} 40$ on L-Glutaminase production was noted. The applied methodology was validated using this optimized media, the enzyme activity $45 \mathrm{IU} / \mathrm{ml}$ in $48 \mathrm{~h}$ of incubation was obtained.
\end{abstract}

Keywords: L-Glutaminase; Production; Optimization; One factor at a time; Streptomyces griseus

\section{INTRODUCTION}

Microbial L-Glutaminases or Glutaminases (Lglutamine amido hydrolase EC 3.5.1.2) have found applications in several fields. L-Glutaminase activity is widely distributed in plants, animal tissues and microorganisms including bacteria, yeast and fungi. L-Glutaminase has an essential role in cellular nitrogen metabolism $(1,2,11,15)$.

This enzyme gained importance in industrial and pharmaceutical sectors as an effective therapeutic agent in the treatment of $\operatorname{HIV}(16,27)$ and acute lymphocytic leukaemia (22). The enzyme causes selective death of glutaminedependent tumor cells by depriving these cells of glutamine. The use of enzymes to deprive neoplasms of essential nutrients helps in the treatment of malignancies (22) and as an analytical agent in determination of glutamine and glutamate $(8,24)$, as a biosensing agent in biosensor (19). LGlutaminase enhances the flavor of fermented foods by increasing their glutamic acid content and thereby imparting a palatable taste. $(6,9)$ The use of L-Glutaminase as a flavour enhancing agent in Chinese foods has replaced the use of monosodium glutamate, which is considered allergic to some individuals (20). and in the production of specialty chemicals like threonine by gamma glutamyl transfer reactions (23). Its commercial importance demands the search for new and better yielding microbial strains and economically viable bioprocesses for its large-scale production (10).
Hence, Researchers are involved in the screening of microbial strains and developing different fermentation strategies to improved productivity. Bioprocess is one of the key processes which helps in enhancing the metabolite productivity under a given set of fermentation environment $(12,13)$. Improvement in microbial metabolite production is generally attempted by manipulating the nutritional and incubational parameters of the organism. Combinatorial interactions of medium components with the cell metabolism towards the production of the desired compound are plentiful, and the optimum processes may be developed using an effective experimental design procedure.

To our knowledge reports on the production of LGlutaminase from Streptomyces griseus is scanty. It's an aerobic gram positive filamentous bacteria .In the present investigation, one-factor-at-a-time approach was used to select the best combination of carbon, nitrogen, amino acids, sodium chloride and minerals salts sources and validated the impact of mixed sources on production by Streptomyces griseus under submerged fermentation.

\section{MATERIALS AND METHODS}

\subsection{Medium Components}

Nutrient broth, L-glutamine, Nessler's reagent and other media components and chemicals were procured from Hi-Media Limited, Mumbai, India. For optical density 
measurements, the absorbance was read using UV/Vis Bio Spectrophotometer (EliCo Pvt. Ltd., India).

\subsection{Microorganism and Culture maintenance}

Streptomyces griseus NCIM 2622 procured from NCIM, National Chemical Laboratory, India, was used in the study. The culture was maintained on Nutrient agar medium slants. Inoculated slants were grown in an incubator at $33{ }^{\circ} \mathrm{C}$ for 4 days. After that the slants were stored at $4{ }^{\circ} \mathrm{C}$ in a refrigerator for short-term preservation and sub-cultured every 15 days in the above-mentioned media.

\subsection{Inoculum preparation}

Inoculum was prepared in $250 \mathrm{ml}$ Erlenmeyer flasks containing $100 \mathrm{ml}$ of Nutrient broth liquid medium ( $\mathrm{pH} 7.0$ ). Prepared medium was autoclaved at $121{ }^{\circ} \mathrm{C}(15 \mathrm{lb})$ for $20 \mathrm{~min}$ and then inoculated with Streptomyces griseus raised from Nutrient agar slants. The inoculated flasks were kept on a shaker at $150 \mathrm{rpm}$ for $48 \mathrm{~h}$, and used as the inoculum.

\subsection{Identification of medium components}

Initially optimization of media components required for maximum L-Glutaminase production by Streptomyces griseus was evaluated in $100 \mathrm{ml}$ of $250 \mathrm{ml}$ Erlenmeyer flasks at $33{ }^{\circ} \mathrm{C}$ for $48 \mathrm{hr}$ at $150 \mathrm{rpm}$ by adding $0.002 \%$ of inoculum. The L-Glutaminase production on nutrient broth was used as a control .Subsequently the medium component studied included the effect of different additional carbon sources ( Malt extract, D-glucose, Sucrose, Starch soluble, Tri sodium citrate, Cellobiose Cellulose, D-mannitol, Lactose, Galactose, D-fructose, Maltose ) at10 g/l, effect of additional nitrogen sources (Peptone, Sodium sulphite, Yeast extract, Urea, Tryptone, Gelatin, Sodium nitrate ) at $10 \mathrm{~g} / \mathrm{l}$, effect of additional amino acids (L-glutamic acid, Glycine, L -ascorbic acid, L -glutamine, Cysteine, Alanine ) at $10 \mathrm{~g} / \mathrm{l}$,effect of additional minerals(Zinc sulphate, Mercuric sulphate, Manganous sulphate, Copper sulphate, Ferrous sulphate, Magnesium sulphate, Potassium di hydrogen phosphate, Di potassium hydrogen phosphate, Calcium chloride) at $0.5 \mathrm{~g} / \mathrm{l}$. After identifying the nutrients improving L-Glutaminase production by 'one factor-at-a-time' approach, the four most important nutrients, viz. Galactose, yeast extract, glutamine and Magnesium sulphate were selected as a medium components and finally the effect of sodium chloride concentration $(10-50 \mathrm{~g} / \mathrm{l})$ on above said medium was studied. All the fermentation experiments were carried out in triplicate. The optimum media was identified as $(\mathrm{g} / \mathrm{l})$
Galactose10.0, yeast extract 10.0, glutamine 10.0, Magnesium sulphate 0.5, Potassium di hydrogen phosphate 0.5, Di Potassium hydrogen phosphate 0.5 and Sodium chloride 40.0, on L-Glutaminase production was observed at $48 \mathrm{~h}$.

\subsection{Analytical determinations}

At appropriate time intervals the fermentation broths were harvested for the L-Glutaminase enzyme. The broth was centrifuged at $10000 \mathrm{rpm}$ for $20 \mathrm{~min}$ at $4{ }^{\circ} \mathrm{C}$ in a refrigerated centrifuge and the supernatant obtained was used for further enzyme assay procedures.

\subsection{Determination of Enzyme activity}

L-Glutaminase was assayed according to Imada et al (7). The reaction mixture, containing $0.5 \mathrm{ml}$ of an enzyme preparation , $0.5 \mathrm{ml}$ of L-glutamine $(0.04 \mathrm{M}), 0.5 \mathrm{ml}$ of phosphate buffer $0.1 \mathrm{M}(\mathrm{pH} 8.0)$, and $0.5 \mathrm{ml}$ of distilled water to a total volume of $2 \mathrm{ml}$ solution was incubated at $37^{\circ} \mathrm{C}$ for 30 $\min$. The reaction was stopped by addition of $0.5 \mathrm{ml}$ of $1.5 \mathrm{M}$ Tri chloro acetic acid. Then to $3.7 \mathrm{ml}$ of distilled water, $0.1 \mathrm{ml}$ of the above mixture and $0.2 \mathrm{ml}$ of Nessler's reagent were added and colour developed was read after keeping the mixture at $20^{\circ} \mathrm{C}$ for $20 \mathrm{~min}$ at $450 \mathrm{~nm}$ in a spectrophotometer .Enzyme and substrate blanks were used as controls. One unit of L-Glutaminase activity was defined as the amount of enzyme that liberated $1 \mu \mathrm{mol}$ of ammonia per1min under optimal assay conditions. Assays were done in triplicate and the mean enzyme activity was expressed as International unit per $\mathrm{ml}(\mathrm{IU} / \mathrm{ml})$.

\section{RESULTS AND DISCUSSION}

\subsection{Identification of medium components}

L-Glutaminase production by a Streptomyces griseus under submerged fermentation condition was observed during the course of study and the observation led to an investigation of the potential of L-Glutaminase synthesis towards developing an ideal bioprocess for industrial production of this enzyme. Hence initially the various nutrients and process parameters, which influence LGlutaminase production by Streptomyces griseus under submerged fermentation conditions, were optimized.

\subsection{Effect of additional carbon sources}

Carbon source represents the energy source that will be available for growth of the microorganism. Carbohydrates and related compounds are superior carbon sources for many genera of microbes (18). However, in some cases, addition of a small amount of external carbon may lead to an increase in 
enzyme production. Fig.1 showed the effect of additional carbon source for yield of L-Glutaminase from Streptomyces griseus was variably changed, when the carbon source changed. In this work, we found yield of L-Glutaminase was high as $26.3 \mathrm{IU} / \mathrm{ml}$ by utilized the Galactose as the carbon source.

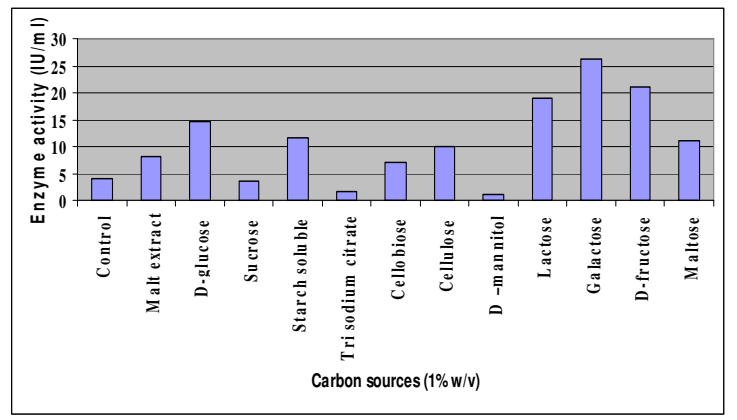

Figure 1: Yield of L-Glutaminase in different carbon source.

\subsection{Effect of additional Nitrogen sources}

Effect of different nitrogen sources (Fig.2) showed that the maximum yield was obtained as $17.5 \mathrm{IU} / \mathrm{ml}$ in presence of yeast extract, because the yeast extract serves as complex Nitrogen source for the metabolic activity. Universal ingredient yeast extract was normally added to media for routine growth and amino acid supplementation was not required in complex media containing yeast extract.

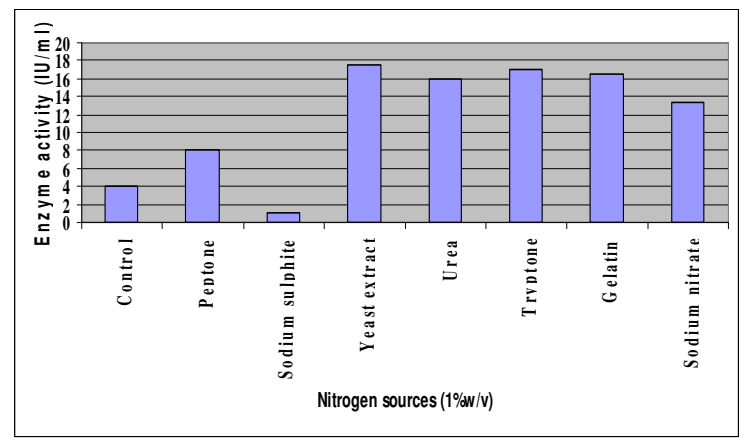

Figure 2: Yield of L-Glutaminase in different Nitrogen source.

\subsection{Effect of additional amino acids sources}

Amino acids were common growth factor required for the synthesis of enzyme as major nitrogen source (4); hence the yield of L-Glutaminase was varied, when the amino acid was changed. Even though each and every amino acid was interchanged by other amino acids, the L-Glutaminase yield was varied according to the nature of amino acids (Fig.3). Yield of L- Glutaminase from the Streptomyces www.ijsea.com griseus was high as $32.7 \mathrm{IU} / \mathrm{ml}$ in L-glutamine. Since Lglutamine is the substrate of L-Glutaminase, the addition to fermentation medium might stimulate enzyme production. It also serves as source of energy and carbon.

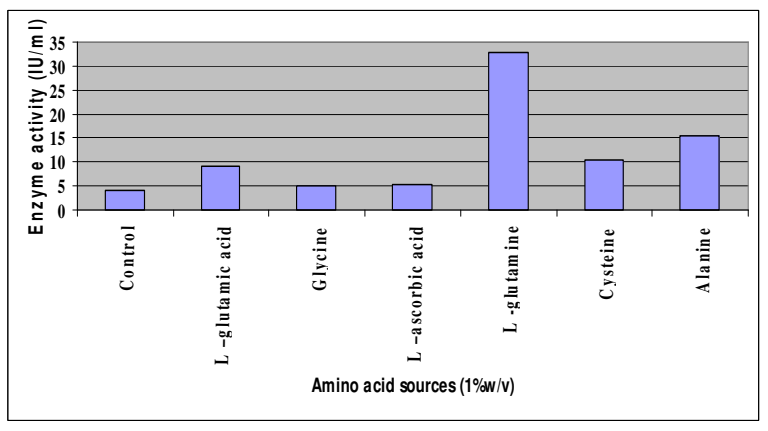

Figure 3: Yield of L-Glutaminase in different Amino acid sources.

\subsection{Effect of additional mineral salt sources}

All the living organisms need some inorganic nutrient for their growth, that do not usually contain the element carbon and when it dissolve in water they separate into ions.L-Glutaminase yield obtained from Streptomyces griseus in the presence of different mineral salts (Fig.4) showed that the maximum yield was $35 \mathrm{IU} / \mathrm{ml}$ in the presence of Magnesium sulphate, $\mathrm{KH}_{2} \mathrm{PO}_{4}$ and $\mathrm{K}_{2} \mathrm{HPO}_{4}$ which is supported both enzyme production and the bacterial growth $(5,14,21,25,26)$.

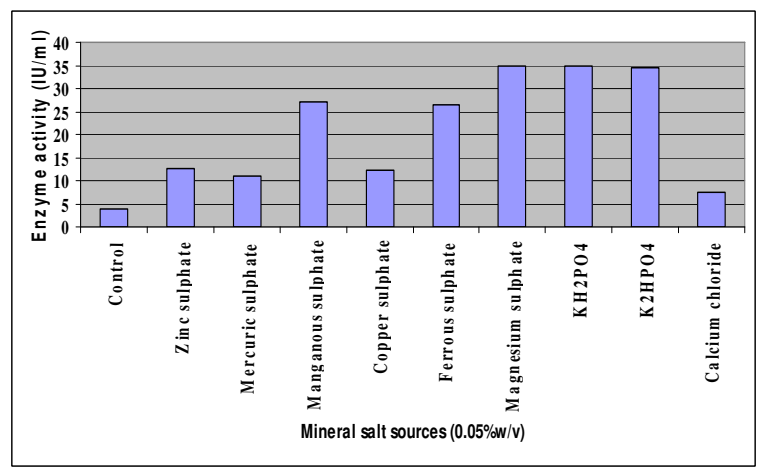

Figure 4: Yield of L-Glutaminase in different Mineral salt sources.

\subsection{Effect of additional sodium chloride}

Yield of L-Glutaminase was increased, when increased the $\mathrm{NaCl}$ concentration up to $4 \%$ as maximum as 45 $\mathrm{IU} / \mathrm{ml}$ and it was low in $1 \%, 2 \%$ and $3 \%$ of $\mathrm{NaCl}$ concentrations (Fig.5). Yield was suddenly decreased, when the concentration was increased above the $4 \%$.Hence, $4 \%$ of $\mathrm{NaCl}$ concentration was the optimum for the production of $\mathrm{L}$ Glutaminase from Streptomyces griseus. The bacteria didn't 
produce more L-Glutaminase without the $\mathrm{NaCl}$ because the Streptomyces griseus were halophilic, the bacteria were unable or try to grow in the low $\mathrm{NaCl}$ concentration, hence there was very low L-Glutaminase production and also the high concentration of $\mathrm{NaCl}$ was also affect the growth of bacteria.

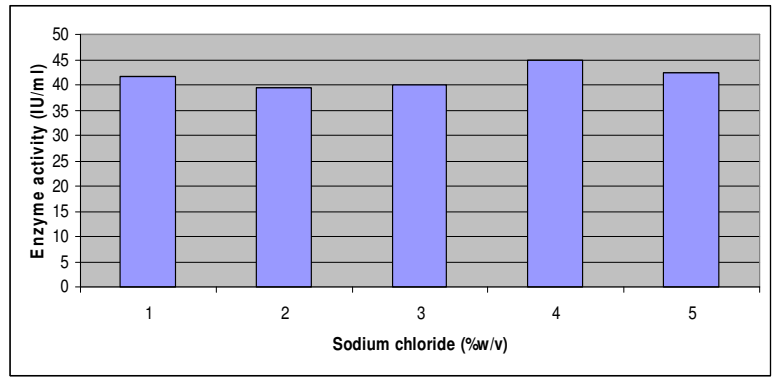

Figure 5: Yield of L-Glutaminase in different concentration of Sodium chloride.

Optimum levels of these significant sources and the effect of their interactions on L-Glutaminase productions were determined by the one -factor- at -a time. The optimized medium components (g/l) Galactose 10.0, Yeast extract10.0, L-Glutamine10.0, Magnesium sulphate 0.5, $\mathrm{KH}_{2} \mathrm{PO}_{4} \quad 0.5$, $\mathrm{K}_{2} \mathrm{HPO}_{4} 0.5, \mathrm{NaCl} 40.0$ on L-Glutaminase production was noted, which gave the maximum enzyme yield of $45 \mathrm{IU} / \mathrm{ml}$.

\section{CONCLUSION}

In this work medium components for higher LGlutaminase production from Streptomyces griseus were optimized by one- factor- at -a time approach. Using one factor at a time approach $(\mathrm{g} / \mathrm{l})$ Galactose 10.0, Yeast extract 10.0,L-Glutamine 10.0,Magnesium sulphate $0.5, \mathrm{KH}_{2} \mathrm{PO}_{4} 0.5$, $\mathrm{K}_{2} \mathrm{HPO}_{4} 0.5 \mathrm{NaCl} 40.0$ were found to be the most significant variables, which significantly enhanced L-Glutaminase production. Using these optimized conditions, the produced enzyme activity of L-Glutaminase reaches $45 \mathrm{IU} / \mathrm{ml}$.

\section{ACKNOWLEDGMENT}

The authors gratefully acknowledge UGC, New Delhi, India for providing financial support to carry out this research work under UGC -Non SAP fellowship scheme. The authors also wish to express their gratitude for the support extended by the authorities of Annamalai University, Annamalainagar, India, in carrying out the research work in Bioprocess Laboratory, Department of Chemical Engineering.

\section{REFERENCES}

[1] Brosnan, J.T., Ewart, H.S. and Squires, S.A. (1995) Hormonal control of hepatic glutaminase. Adv Enzyme Regul 35,131-146.

[2] Carter, P. and Welbourne, T.G. (1997) Glutamate transport regulation of renal glutaminase flux in vivo. J Physiol 273,521-527.

[3] Cavalitto, S.F., Mignone, C.F., 2007. Application of factorial and Doehlert designs for optimization of protopectinase production by a Geotrichum klebahnii strain. Proc. Biochem. 42, 175-179.

[4] Cruz Soto, R., Muhammed, S. A., Newbold, C. J., Stewart, C. S., and Wallace,R. J., 1994, Influence of peptides, amino acids and urea on microbial activity in sheep receiving grass hay and on the growth of rumen bacteria in vitro, Animal Feed Sci. Tech., 49, pp. 151-161.

[5] Clyde Eyster, 1959, Growth inhibition of Chlorella pyrenoidosa produced by sodium dihydrogen phosphate and its reversal by calcium, Plant and Soil,11(3), pp. 207-214.

[6] Chou, C.C. and Hwan, C.H. (1994) Effect of ethanol on the hydrolysis of protein and lipid during the ageing of a Chinese fermented soya bean curd-sufu. J Sci Food Agric66, 393-398.

[7] Imada A, Igarasi S, Nakahama K, Isono M. Asparaginase and Glutaminase activities of microrganisms. J Gen Microbiol 1973;76:85-99.

[8] Mulchandani, A. and Bassi, A.S. (1996) Determination of glutamine and glutamic acid in mammalian cell cultures using tetrathiafulvalene modified enzyme electrodes. Biosensor Bioelectron 11, 271-280.

[9] Nakadai, T. and Nasuno, S. (1989) Use of glutaminase for soy sauce made by Koji or a preparation of proteases from Aspergillus oryzae. J Ferment Bioeng 67, 158-162.

[10] Nagendra Prabhu, G., \& Chandrasekaran, M. (1997). Impact of process parameters on L-glutaminase production by marine Vibrio costicola in solid state fermentation using polystyrene as an inert support Process Biochemistry, 32, 285-289.

[11] Padma ,I and Singhal, R.S. (2007) Production of glutaminase(E.C.3.5.1.2) from Zygosaccharomyces rouxii: statisticaloptimization using response surface methodology. Bioresource Technology 99, 4300-4307. 
International Journal of Science and Engineering Applications (IJSEA)

Volume 2 Issue 1, 2013, ISSN - 2319-7560 (online)

[12] Prakasham, R.S., Rao, Ch.S., Rao, R.S., Lakshmi, G.S. and Sarma, P.N. (2007a) L-asparaginase production by isolated Staphylococcus sp. - 6A: design of experiment considering interaction effect for process parameter optimization.J Appl Microbiol 102, 1382-1391.

[13] Park, Y., Kang, S., Lee, J., Hong, I., Kim, W., 2002. Xylanase production in solid state fermentation by Aspergillus niger mutant using statistical experimental designs. Appl. Microbiol. Biotechnol. 58, 761-766.

[14] Pandey, D. K., and Gupta, S. C., 1966, Studies in pectic enzymes of parasitic fungi-VI. Factors affecting the secretion of pectic enzymes by Alternaria tenuis, Biologia Plantarum, 8(2), pp. 131-141.

[15] Riberg, B., Torgner, I.A. and Kvamme, E. (1995) The orientationof phosphate activated glutaminase in the inner mitochondrial membrane of synaptic and non-synaptic rat brain mitochondria. Neurochem Int 27, 367-376.

[16] Roberts, J., MacAllister, T.W., Sethuraman, N. and Freeman,A.G. (2001) Genetically engineered glutaminase and its use in antiviral and anticancer therapy. US Patent, 6312939.

[17] Rathi, P., Saxena, R., Gupta, R., 2001. A novel alkaline lipase from Burkholderia cepacia for detergent formulation. Proc. Biochem. 37,187-192.

[18] Rosalie J. Cote, 1999, Media composition, microbial and Laboratory scale,In: Encyclopedia of bioprocess technology: Fermentation, biocatalysis and bioseparation, Michael and Stephen, eds., John Wiley \& Sons Inc., New York,Volume 15: $1640-1660$

[19] Sabu, A., Keerthi, T.R., Kumar, S.R. and Chandrasekaran, M.(2000b) L-Glutaminase production by marine Beauveria sp. under solid state fermentation. Process Biochem 35,705-710.

[20] Sabu, A., Chandrasekaran, M., Pandey, A., 2000. Biopotential of microbial glutaminases. Chem. Today 18, 2125.
[21] Salwa Khalaf and Ashraf El-Sayed, 2009, Methioninase production by filamentous fungi: I-screening and optimization under submerged conditions, Curr. Microbiol., 58(3), pp. 219226. DOI: $10.1007 / \mathrm{s} 00284-008-9311-9$.

[22] Schmid, F.A. and Roberts, J. (1974) Antineoplastic and toxic effects of Acinetobacter and Pseudomonas glutaminaseasparaginases. Cancer Chemother Rep 58, 829-840.

[23] Tachiki, T., Yamada, T., Mizuno, K., Ueda, M., Shiode, J. and Fukami, H. (1998) $\gamma$-Glutamyl transfer reactions by glutaminase from Pseudomonas nitroreducens IFO 12694 and their application for the syntheses of theanine and $\gamma$ glutamylmethylamide. Biosci Biotechnol Biochem 62,12791283.

[24] Villarta, R.L, Palleschi, G., Suleiman, A. and Guilbault, G.G.(1992) Determination of glutamine in serum using an amperometric enzyme electrode. Electroanalysis 4, 27-31.

[25] Yugandhar, N. M., Ravi Kumar, D.V. R., Prasanthi, V., Kiran Kumar, N., and Sri Rami Reddy, D., 2008, Optimization of pectinase production from Manihot utilissima by Aspergillus niger NCIM 548 using statistical experimental design, Res. J. Microbiol., 3(1), pp. 9-16.

[26] Yousuke Taoka, Naoki Nagano, Yuji Okita, Hitoshi Izumida, Shinichi Sugimoto and Masahiro Hayashi, 2008, Effect of addition of Tween 80 and Potassium dihydrogen phosphate to basal medium on the isolation of marine eukaryotes, Thraustochytrids, J. Biosci. Bioeng., 105(5), pp. $562-565$.

[27] Zhao, J., Lopez, A.L., Erichsen, D., Herek, S., Cotter, R.L., Curthoys, N.P. and Zheng, J. (2004) Mitochondrial glutaminase enhances extracellular glutamate production in HIV-1-infected macrophages: Linkage to HIV-1 associated dementia. J Neurochem 88, 169-180. 